\title{
DESKRIPSI ANALISIS KEMAMPUAN MENGAJAR MAHASISWA PPL BIDANG STUDI PENDIDIKAN FISIKA SEMESTER VI PADA FAKULTAS TARBIYAH DAN KEGURUAN IAIN RADEN INTAN LAMPUNG
}

\author{
Yuberti \\ Fakultas Tarbiyah dan Keguruan IAIN Raden Intan Lampung \\ Jalan Endro Suratmin Sukarame Bandar Lampung \\ Email: yuberti_iain@yahoo.co.id
}

\begin{abstract}
Abstrak:
Penelitian ini bertujuan untuk mengetahui kemampuan mahasiswa dalam menyusun Komponen RPP, pelaksanaan pembelajaran, komponen kepribadian dan sosial dan komponen laporan PPL. Penelitian ini mengggunakan metode deskriptif dengan pengumpulan data melalui survey. Populasi adalah semua peserta PPL Pendidikan Fisika semester VI. Sampel dengan teknik total sampling dengan jumlah 30 orang. Berdasarkan hasil analisis ditemukan: (1). Penilaian Komponen RPP; memperoleh nilai rata-rata 3,77 dari nilai total yang menjadi acuan pedoman penilaian PPL; (2). Penilaian Komponen Pelaksanaan Pembelajaran; mendapatkan nilai rata-rata 3,78, dari nilai total yang menjadi acuan pedoman penilaian PPL. (3). Penilaian Komponen Kepribadian dan Sosial; rata-rata mendapatkan nilai 3,84, dari nilai total yang menjadi acuan pedoman penilaian PPL. (4). Penilaian Komponen Laporan PPL; mendapatkan nilai dengan rata-rata 3,65 dari nilai total yang menjadi acuan pedoman penilaian PPL.
\end{abstract}

\begin{abstract}
:
This study aimed to determine the ability of the students in preparing the lesson plan components, implementation of learning, personality and social components and pre service teaching reports. This research is a descriptive methods using surveys as collection data. The populations were all of the pre service students of physical education department. The samples were taken by using census sampling which were totally 30 . Based on the data analysis, it is found that: (1) The assessment of lesson plan components obtains an average value of 3.77 of the total value of the reference pre service teaching assessment guidelines; (2) The assessment of learning implementation component obtains an average value of 3.78 of the total value of the reference pre service teaching assessment guidelines. (3). The assessment of personality and social components obtains an average value of 3.84 of the total value of the reference pre service teaching assessment guidelines. (4) The assessment of pre service teaching report obtains the average value of 3.65 of the total value of the reference pre service teaching assessment guidelines.
\end{abstract}

Kata kunci :

Kemampuan Mengajar, Mahasiswa PPL

KEGIATAN PPL adalah serangkaian kewajiban yang harus ditempuh mahasiswa untuk dapat memperoleh sebagian persyaratan menyelesaikan pendidikan di sebuah perguruang tinggi. Mahasiswa Fakultas Tarbiyah dan Keguruan merupakan salah satu Fakultas di Institut Agama Islam Negeri (IAIN) Raden Intan yang di dalam kurikulumnya mewajibkan mahasiswa untuk menempuh dan menyelesaikan kegiatan PPL pada satuan pendidikan yang berada di wilayah Jakarta dan sekitarnya. Melalui ke- 
giatan PPL diharapkan mahasiswa memiliki pengalaman langsung, bagaimana menyelenggarakan kegiatan pengajaran pada satu satuan pendidikan baik SD, SMP atau SMU.

Kegiataan PPL mahasiswa pendidikan fisika merupakan salah satu kegiatan akademik yang harus ditempuh mahasiswa program studi pendidikan fisika sebelum mahasiswa menyelesaikan studi di Fakultas Tarbiyah dan Keguruan pada Institut Agama Islam Negeri (IAIN) Raden Intan Lampung. Seperti diketahui IAIN menyelenggaraan pendidikan dalam berbagai displin ilmu baik disiplin ilmu kependidikan maupun nonkependidikan. Program kependidikan sendiri diselenggarakan sebagai amanat kepercayaan pemerintah kepada IAIN untuk menyediakan tenaga kependidikan seperti yang tercantum dalam Keppres 093/1999 tanggal 4 agustus 1999.6 Sesuai dengan visi dan misi IAIN Raden Intan, program kependidikan ini akan tetap dikembangkan secara optimal sebagai Lembaga Pendidik Tenaga Kependidikan (LPTK).

Penyelenggaraan PPL sendiri hanya berlaku bagi mahasiswa Program Sarjana (S1). Dimana Program Sarjana S1 bertujuan menghasilkan lulusan yang memiliki kualifikasi:

1. Menguasai dasar-dasar ilmiah dan keterampilan dalam bidang keahlian tertentu sehingga mempu menemukan, memahami, menjalaskan dan merumuskan cara penyelesaian masalah yang ada di dalam kawasan keahliannya

2. Mampu menerapkan ilmu pengetahuan dan keterampilan yang dimilikinya sesuai dengan bidang keahliannya dalam kegiatan produktif dan pelayanan kepada masyarakat dengan sikap dan perilaku yang sesuai dengan tata kehidupan bersama

3. Mampu bersikap dan berprilaku dalam membawakan diri di bidang keahliannya maupun dalam berkehidupan bersama di masyarakat

4. Mampu mengikuti perkembangan ilmu pengetahuan, teknologi dan atau seni yang merupakan keahliannya.

Berdasarkan kualifikasi tersebut mahasiswa kependidikan program studi S1 harus menyelesaikan beban studi sebanyak 144-146 sks dimana program PPL termasuk salah satunya. Program PPL masuk ke dalam praktek kompetensi pembelajaran yang bertujuan untuk memberikan pengalaman belajar kepada mahasiswa di sekolah sebagai tempat praktek.

Kemampuan mengajar adalah sesuatu yang dimiliki untuk memenuhi tugas atau pekerjaan yang dibebankan kepadanya, dalam hal ini pekerjaan dan beban kaitan dalam mengajar. Kemampuan mengajar mahasiswa PPL merupakan serangkaian kegiatan mahasiswa dalam praktek latihan mengajar pada salah satu satuan pendidikan. Program PPL bagi mahasiswa menjadi sarana pembelajaran mahasiswa dan mengaplikasikan keseluruhan kemampuannya dalam mengelola kelas dan menyelenggarakan kegiatan pengajaran berdasarkan teori-teori yang sudah diperoleh di bangku kuliah. Bekal pengalaman mengajar itu langsung dipraktekkan pada siswa pada masing-masing satuan pendidikan akan memberikan pengalaman nyata bagi mahasiswa kelak ketika mahasiswa akan menjadi guru sesungguhnya. 
Begitu pula kegiatan PPL yang ditempuh oleh mahasiswa program studi pendidikan Fisika pada semester ganjil periode akademik Juli-Desember 2012. Bagaimana program praktek pengenalan lapangan ini terselenggara di satuan pendidikan terkait dengan serangkaian kompetensi yang harus dikuasai dengan baik, bagaimana menyusun Rencana pelaksanaan Pembelajaran (RPP), bagaimana Pelaksanaan Pembelajaran, bagaimana Kepribadian dan Sosial mahasiswa selama menjalankan program PPL, dan bagaimana mahasiswa merangkum keseluruhan kegatan PPL selama satu semester, semua komponen tersebut merupakan data selama kegiatan PPL berlangsung dan perlu dilakukan evaluasi agar menjadi bahan masukan untuk pelaksanaan di kemudian hari.

\section{METODE PENELITIAN}

Penelitian ini bertujuan untuk mengetahui kemampuan mahaiswa dalam menyusun Komponen RPP, pelaksanaan pembelajaran, komponen kepribadian dan sosial dan komponen laporan PPL. Penelitian ini mengggunakan metode deskriptif dengan pengumpulan data melalui survey. Pengumpulan data kemampuan mengajar mahasiswa PPL bidang studi Pendidikan Fisika semester VI berdasarkan persepsi guru pamong. Populasi dari penelitian ini adalah semua peserta PPL Pendidikan Fisika semester VI. Sampel dalam penelitian diambil dengan teknik total sampling dengan jumlah 30 orang.

\section{HASIL PENELITIAN}

Tabel 1. Nilai Rata-rata

\begin{tabular}{|c|c|c|c|c|}
\hline Komponen & RPP & $\begin{array}{c}\text { Pelaksanaan } \\
\text { Pebelajaran }\end{array}$ & $\begin{array}{c}\text { Kepribadian } \\
\text { dan Sosial }\end{array}$ & $\begin{array}{c}\text { Laporan } \\
\text { Akhir PPL }\end{array}$ \\
\hline Rata-rata Nilai & 3.77 & 3.78 & 3.84 & 3.65 \\
\hline
\end{tabular}

Dari data yang telah terkumpul dari Survey Tentang kompetensi mahasiswa PPL Pendidikan Fisika diperoleh data sebagai berikut:

\section{Penilaian Komponen Rencana Pelaksanaan Pembelajaran (RPP)}

Data di atas menunjukan hasil penilaian terhadap mahasiswa PPL dalam membuat rencana pelaksanaan pembelajaran pada 30 orang responden memperoleh nilai 3,77 dari nilai total yang menjadi acuan pedoman penilaian PPL. Sedangkan berdasarkan nilai rata-rata tersebut, di dalam distribusi frekuensi, diketahui ada 12 orang (40\%) skor penilain RPP di bawah kelas rata-rata, 12 orang pada kelas rata-rata (40\%) dan 6 orang di atas kelas rata-rata $(20 \%)$.

Jika dibandingkan di dalam kelas interval, terlihat sejumlah mahasiswa yang berada di kelas rata-rata dan di bawah kelas rata-rata, untuk komponen Rencana pelaksanaan Pembelajaran (RPP) memiliki jumlah sama yaitu 12 orang (40\%) dan dari jumlah tersebut dapat dikatakan mahasiswa masih berada di kelas rata-rata. Berdasarkan data tersebut maka sepatutnya mahasiswa dapat mempelajari kembali bagai- 
mana penyusunan rencana pelaksanaan pembelajaran (RRP) dengan lebih baik lagi sehingga jika di konversi ke dalam nilai kemampuan mahasiswa dalam menyusun RRP akan diperoleh skor yang lebih baik yaitu skor dari jumlah mahasiswa yang mengikuti PPL akan mencapai sejumlah mahasiswa yang lebih banyak lagi dikelas rata-rata bahkan di atas kelas rata-rata.

\section{Penilaian Komponen Pelaksanaan Pembelajaran}

Berdasarkan tabel 1 menunjukan hasil penilaian terhadap mahasiswa PPL dalam Komponen Pelaksanaan Pembelajaran, pada 30 orang responden mendapatkan nilai dengan rata-rata 3,78, dari nilai total yang menjadi acuan pedoman penilaian PPL. Sedangkan berdasarkan nilai rata-rata tersebut, di dalam distribusi frekuensi, ada 3 orang (10\%) yang skor penilain kemampuan melaksanakan pembelajaran di bawah kelas rata-rata, 25 orang pada kelas rata-rata $(83,33 \%)$ dan 2 orang di atas kelas rata-rata $(6,67 \%)$.

Sehingga jika dibandingkan di dalam kelas interval, terlihat jumlah mahasiswa masih berada di kelas rata-rata dengan jumlah yang cukup representative yaitu mencapai $83,33 \%$ (25 orang). Dengan data tersebut dapat dikatakan bahwa pelaksanaan kegiatan pembelajaran mahasiswa pendidikan fisika yang mengikuti PPL semester VI telah dapat melaksanakan kegiatan mengajar cukup baik karena jumlah mereka lebih banyak berada di dalam kelas rata-rata yaitu 83,33\% (25 orang). Dengan demikian tetap diperlukan peningkatan agar jumlah mahasiswa yang lebih banyak adalah mereka yang berada di atas kelas rata-rata.

\section{Penilaian Komponen Kepribadian dan Sosial}

Berdasarkan tabel 1 menunjukan hasil penilaian terhadap mahasiswa PPL dalam Komponen Kepribadian dan Sosial, pada 30 orang responden, rata-rata mendapatkan nilai 3,84, dari nilai total yang menjadi acuan pedoman penilaian PPL. Sedangkan berdasarkan nilai rata-rata tersebut ada 16 orang $(53,33 \%)$ skor penilain komponen kepribadian dan sosial di bawah kelas rata-rata, 1 orang pada kelas rata-rata $(3,33 \%)$ dan 13 orang di atas kelas rata-rata $(43,33 \%)$.

Sehingga jika dibandingkan di dalam kelas interval, terlihat jumlah mahasiswa masih kurang karena mahasiswa yang berada di bawah kelas rata-rata mencapai 16 orang (53,33\%) lebih dari 50\%. Dengan demikian perlu kembali ditingkatkan komponen terkait kepribadian dan sosial mahasiswa di dalam kegiatan PPL karena komponen ini juga membentuk kemampuan mahasiswa untuk dapat menjadi seorang guru yang seutuhnya.

\section{Penilaian Komponen Laporan PPL}

Berdasarkan tabel 1 menunjukan hasil penilaian terhadap mahasiswa PPL dalam membuat laporan pelaksanaan PPL pada 30 orang responden mendapatkan nilai dengan rata-rata 3,65 dari nilai total yang menjadi acuan pedoman penilaian PPL. Sedangkan berdasarkan nilai rata-rata tersebut ada 10 orang (33,33\%) skor penilain komponen laporan PPL di bawah kelas rata-rata, 8 orang pada kelas rata-rata 
$(26,67 \%)$ dan 12 orang di atas kelas rata-rata (40\%). Berdasarkan data tersebut maka kemampuan mahasiswa dalam menyusun laporan kegiatan PPL sudah dapat dilakukan dengan baik, terbukti sejumlah 12 orang (40\%) mahasiswa memperoleh nilai di atas kelas rata-rata. Dengan demikian pertahankan kemampuan yang sudah baik dan tetap perlu ditingkatkan kembali agar sejumlah mahasiswa lebih banyak lagi nilainya di atas kelas rata-rata.

\section{PEMBAHASAN}

Kemampuan mengajar guru pendidikan fisika merupakan interaksi pedagogis antara guru, siswa, materi dan lingkungannya. ${ }^{1}$ Lutan $\mathrm{dkk}$ menyatakan sebagai kegiatan mengelola persiapan, dan keterkaitan empat unsur pengajaran yaitu tujuan, tugas ajar, metode dan strategi, asesmen serta evaluasi. ${ }^{2}$ Dauer dan Pangrazi mendefinisikan bahwa kemampuan mengajar guru pendidikan fisika adalah bagaimana efektivitas manajemen guru di dalam kelas. ${ }^{3}$

Berdasarkan penjelasan di atas disimpulkan bahwa kemampuan mengajar guru pendidikan fisika adalah fungsi profesi sebagai guru pendidikan fisika dimana dengan profesinya tersebut guru pendidikan fisika dituntut memiliki kemampuan membuat keputusan dan kebijakan yang tepat. Seperti membuat sebuah perencanaan dan melaksanakan proses pembelajaran, menilai hasil pembelajaran, melakukan pembimbingan dan pelatihan, membantu pengembangan dan pengelolaan program sekolah serta mengembangkan profesionalisme dengan kegiatan-kegiatan lainnya yang bermanfaat.

Sebagai perencana, guru pendidikan fisika dituntut untuk menyusun rencana kegiatan pembelajaran semesteran, mingguan, juga bekerja sama dengan guru pendidikan fisika lainnya untuk menyusun kegiatan tahunan. Sebagai pengelola guru pendidikan fisika diharapkan dapat mengelola semua sumber daya yang ada di sekolah seperti alat dan media pembelajaran, pengelompokkan peserta didik, orang tua peserta didik, sarana dan prasarana dengan sebaik-baiknya. Sebagai pendidik fisika profesional, karena peran khusus yang berbeda dengan guru kelas. Sebagai penyuluh guru pendidikan fisika diminta untuk mampu memberikan bimbingan dan penyuluhan kepada peserta didik yang mengalami masalah dalam belajar dan permasalahan sekitar pendidikan lainnya.

Dewan pendidikan fisika, council on physical education for children (COPEC) Amerika Serikat menyaratkan sembilan kemampuan yang harus dimiliki oleh guru pendidikan fisika:

1. Mampu mengidentifikasi karakteristik pertumbuhan dan perkembangan peserta didik.

2. Mampu membangkitkan dan memberikan kesempatan peserta didik berkreasi dan aktif dalam proses pembelajaran.

3. Mampu memberikan bimbingan dan penyuluhan pada peserta didik.

4. Mampu merencanakan, melaksanakan, mengendalikan dan menilai serta mengoreksi setiap pembelajaran pendidikan fisika. 
5. Memiliki pemahaman dan penguasaan keterampilan mengajar.

6. Memiliki pemahaman unsur-unsur dalam pembelajaran fisika.

7. Mempu menciptakan, mengembangkan dan memanfaatkan faktor lingkungan yang ada.

8. Mampu mengidentifikasi potensi anak didik dalam ilmu pengetahuan alam.

9. Mampu menyalurkan hobinya dalam kegiatan Ilmu pengetahuan alam.

Ketika menyusun rencana pembelajaran pendidikan fisika kemampuan mengidentifikasi karakteristik pertumbuhan dan perkembangan anak usia sekolah pada masing-masing satuan pendidikan diperlukan oleh guru pendidikan fisika supaya materi pelajaran yang diberikan sesuai dengan tahap pertumbuhan dan perkembangan peserta didik. Akan berakibat tidak baik untuk anak didik jika materi pelajaran diberikan tidak sesuai dengan tahap pertumbuhan dan perkembangannya. Misalnya mengenai anak kelas I Madrayah Aliyah akan takut untuk mengerjakan soal-soal yang berkaitan dengan fisika. Membangkitkan semangat dan memberi kesempatan anak didik untuk berkreasi dan aktif dalam kegiatan pembelajaran merupakan salah satu syarat keberhasilan belajar. Anak didik yang kurang semangat belajarnya akan menimbulkan kendala dalam mengikuti kegiatan pembelajaran pendidikan fisika, disini guru berperan sebagai motivator. Memberikan kesempatan yang sama kepada anak didik untuk berkreasi dan aktif dalam kegiatan pembelajaran pendidikan fisika sebaiknya dilakukan dalam setiap kegiatan pembelajaran, dan jika kurang memberikan kesempatan kepada peserta dididk untuk berkreasi dan ikut aktif dalam kegiatan pembelajaran pendidikan fisika, menyebabkan mereka kurang antusias dalam belajarnya.

Memberikan bimbingan dan penyuluhan pada anak didik dalam kegiatan pembelajaran pendidikan fisika merupakan tugas yang penting, sebab kesalahan yang dilakukan oleh anak didik dalam mempelajari gerak harus segara diperbaiki. Demikian juga jika ada anak didik yang mengalami kesulitan atau kurang senang dengan mata pelajaran pendidikan fisika, guru secepat mungkin mencari tahu penyebabnya, mendiagnosa, dan memberikan penyuluhan. Merencanakan suatu kegiatan pembelajaran adalah mutlak diperlukan agar pelaksanaan kegiatan pembelajaran terarah, tidak asal-asalan atau dapat dikendalikan oleh guru dengan baik sehingga kegiatan pembelajaran lancar. Menilai dan mengoreksi gerak yang dilakukan oleh anak didik dalam kegiatan pembelajaran pendidikan fisika agar tidak hanya dilakukan untuk mendapatkan nilai akhir saja, melainkan juga melakukan koreksi dan menilai proses berlangsungnya pembelajaran.

Memahami dan menguasai keterampilan mengajar bagi guru pendidikan fisika diperlukan untuk memberikan contoh pembelajaran yang benar. Sangat sedikit mahasiswa yang sudah menguasai keterampilan ini, termasuk unsur-unsur penguasaan kelas, penguasaan materi, dan interaksi yang baik. Jika mahasiswa memiliki kemampuan yang baik, maka belajar materi fisika akan dilakukan dengan baik dan menyenangkan. 
Menciptakan, mengembangkan dan memanfaatkan lingkungan baik yang ada di dalam sekolah maupun di luar sekolah akan dapat menunjang kegiatan pembelajaran. Setiap minggu, lama belajar mahasiswa program fisika selama 105 jam. Pemanfaatan waktu di luar waktu tersebut akan mengefektifkan proses pembelajaran di samping menghubungkan peserta dengan lingkungannya.

Adalah tidak mungkin untuk melepaskan hubungan peserta didik dengan lingkungannya, karena hal itu berarti mengisolasi anak dengan kehidupannya. Dari jumlah anak didik yang diajar oleh guru pendidikan fisika, terdapat ada anak didik yang memilih keterampilan lebih dari keterampilan yang dimiliki gurunya. Guru yang jeli akan mengidentifikasi potensi anak tersebut untuk dibimbing dan difasilitasi sesuai dengan potensinya, melalui kegiatan ekstrakurikuler atau berlatih di perkumpulan.

Kemampuan mengajar menuntut guru dalam merencanakan materi pelajaran, mempertimbangkan dan menentukan urutan-urutan yang akan disajikan. Untuk membuat urutan materi pelajaran pertimbangan utama yang perlu diperhatikan adalah tingkat kesulitan dan kompleksitas materi belajar yang akan disusun urutannya. Berdasarkan pertimbangan tingkat kesulitan dan tingkat kompleksitasnya, penyusunan materi pelajaran hendaknya mengikuti prinsip-prinsip: (1) dimulai dari materi belajar yang mudah dan selanjutnya secara berangsur-angsur ke materi yang semakin sukar, dan (2) dimulai dari materi belajar yang sederhana dan selanjutnya secara berangsur-angsur ke materi yang semakin kompleks. Seorang guru sebaiknya juga memiliki kompetensi mengajar dasar gerak yang bersifat umum, yang mencakup: penguasaan dan mengorganisasi materi yang hendak diajarkan dan penguasaan metode penyampaian serta penilaiannya. ${ }^{4}$ Sistematika pengajaran Pendidikan Fisika dapat dibagi menjadi tiga bagian yaitu pendahuluan, inti dan penutup. ${ }^{5}$

Kegiatan pendahuluan pada prinsipnya adalah kegiataan yang dilakukan untuk memusatkan kembali perhatian anak kepada pengajaran yang akan berlangsung. Pada kegiatan pendahuluan dapat dilakukan kegiatan seperti kegiatan membuka kelas, memeriksa kehadiran anak, penjelasan singkat tujuan pengajaran yang akan dicapai serta sampai kepada kegiatan pemanasan yang berupa rangsangan materi yang telah dipelajari sebelumnya.

Kegiatan selanjutnya adalah inti pembelajaran, dimana pada kegiatan ini guru berupaya untuk menciptakan perubahan tingkah laku anak sesuai dengan tujuan yang sudah ditetapkan. Pada kegiatan inti yang harus diingat guru adalah dilaksanakannya kegiatan dalam bentuk penyediaan pengalaman gerak untuk menguasai suatu keterampilan. Penyediaan pengalaman gerak dilakukan dengan memperhatikan tahapan belajar keterampilan gerak melalui tiga tahapan yaitu; kognisi, asosiasi dan otomatisasi. Kegiatan kognisi dilakukan dengan memberikan penjelasan melalui contoh gerakan maupun informasi verbal keseluruhan gerakan yang akan dipelajari. Asosiasi adalah tahapan dimana guru memberikan kesempatan kepada anak untuk dapat melakukan dan mengulang kembali gerakan secara keseluruhan. Otomatisasi adalah tahapan dimana peserta didik dapat mengulanginya meski tanpa pengawasan guru. Perlu diingat selama anak mencoba dan mengulang materi yang telah dicontoh- 
kan sebelumnya, agar diberi motivasi dan koreksi-koreksi terhadap penampilan kemampuan yang ditunjukkan oleh anak.

Kegiatan selanjutnya adalah penutup, penutup merupakan kegiatan akhir dari proses pengajaran gerak secara keseluruhan. Pada kegiatan ini harus dilakukan kembali kegiatan penenangan dan evaluasi kegiatan pembelajaran. Penenangan dilakukan untuk mengembalikan kesegaran seperti sebelum dimulainya pembelajaran tujuannya agar anak siap kembali melakukan aktivitas belajar lainnya. sedangkan evaluasi dilakukan untuk mengkoreksi dan menambahkan hal-hal yang penting selama pelaksanaan kegiatan pendahuluan dan inti sehingga hal-hal yang masih belum dapat dilakukan dan perlunya pengulangan pada kesempatan lainnya dapat dipahami dan menjadi pengalaman baik bagi anak. Evaluasi juga dapat dilakukan untuk perencanaan kegiatan belajar mengajar yang akan datang.

Ada beberapa kompetensi yang harus dipenuhi sebagai seorang guru yaitu kompetensi pedagogik, kepribadian, sosial dan professional. Kompetensi pedagogik, adalah kemampuan mengelola pembelajaran peserta didik yang meliputi pemahaman terhadap peserta didik, perencanaan dan pelaksanaan pembelajaran, evaluasi hasil belajar, dan pengembangan peserta didik untuk mengaktualisasikan berbagai potensi yang dimilikinya. Kompetensi kepribadian adalah kemampuan kepribadian yang mantap, stabil, dewasa, arif, dan berwibawa, menjadi teladan bagi peerta didik dan berakhlak mulia. Kompetensi professional merupakan kemampuan penguasaan materi pembelajaran secara luas dan mendalam yang memungkinkan untuk membimbing peserta didik agar dapat memenuhi standar kompetensi yang ditetapkan dalam Standar Nasional Pendidikan. Sedangkan kompetensi sosial merupakan kemampuan guru sebagai bagian dari masyarakat untuk berkomunikasi dan bergaul secara efektif dengan peserta didik, sesama pendidik, tenaga kependidikan, orang tua wali, peserta didik, dan masyarakat sekitar.

Berdasarkan penjelasan pernyataan di atas maka selayaknya seorang guru pendidikan fisika dapat menyelenggarakan pendidikan sesuai dengan tuntutan kurikulum serta tumbuh dan kembang peserta didik. Penyelenggaraan pendidikan diselenggarakan sebagai sarana untuk menggali potensi fisik, emosi, intelektual dan lingkungan yang telah dimiliki peserta didik, sehingga dapat menguji potensi yang dimiliki untuk mencapai tujuan pendidikan yang ditetapkan.

\section{SIMPULAN}

Berdasarkan penjelasan di atas disimpulkan bahwa kemampuan mengajar guru pendidikan fisika diperlukan untuk menjalankan fungsi profesinya sebagai guru pendidikan fisika. Profesi guru pendidikan fisika menuntut kemampuan membuat keputusan yang tepat dan kemampuan membuat kebijaksanaan yang tepat. Membuat sebuah perencanaan dan melaksanakan proses pembelajaran, menilai hasil pembelajaran, melakukan pembimbingan dan pelatihan, melakukan penelitian, membantu pengembangan dan pengelolaan program sekolah serta mengembangkan profesionalisme harus ditangani dan dilakukan dengan baik oleh seorang guru pendidikan fisika. 


\section{CATATAN AKHIR}

1. Adang Suherman, Revitalisasi pengajaran dalam Pendidikan Fisika, Bandung: Bintang WarliArtika, 2009, h. 50.

2. Rusli Lutan., Rusli Ibrahim., Adang Suherman., Yudha M. Saputra., Supervisi Pendidikan Fisika Konsep dan Praktik, Jakarta: Depdiknas Direktorat Jendral Pendidikan Dasar \& Menengah, 2002, h. 76.

3. Robert P. Pangrazi and Victor P. Dauer., Dynamic Physical Education For Elementary School Childrens Tenth Edition, 1992, h. 109.

4. Rusli Rustan, dkk, op. cit., h. 90-93.

\section{DAFTAR PUSTAKA}

Fathurrohman, Pupuh dan Sobry Sutikno, Strategi Belajar Mengajar Melalui Penanaman Konsep Umum dan Konsep Islami, Jakarta: PT Refika Aditama, 2007.

Lutan, Rusli, Rusli Ibrahim., Adang Suherman., Yudha M. Saputra. Supervisi Pendidikan Fisika Konsep dan Praktik, Jakarta: Depdiknas Direktorat Jendral Pendidikan Dasar \& Menengah, 2002.

Mulyasa, E. Kurikulum Berbasis Kompetensi: Konsep, Karakteristik dan Implementasi, Bandung: PT Remaja Rosdakarya, 2003.

Mulyasa, E. Standar Kompetensi dan Sertifikasi Guru, Bandung: PT Remaja RosdaKarya, 2008.

Muslich, Masnur. Sertifikasi Guru Menuju Profesionalisme Pendidik, Jakarta: Bumi Aksara, 2007.

Pangrazi, Robert P., and Victor P. Dauer. Dynamic Physical Education For Elementary School Childrens, Tenth Edition, 1992.

Siedentop, Darly. Introduction to Physical Education, Fitness and Sport, Mountain View, California: Mayfield Publising Company, 1994.

Suherman, Adang. Revitalisasi Pengajaran dalam Pendidikan Fisika, Bandung: Bintang WarliArtika, 2009. 